\title{
Record of shallow-water sponges in Simeulue Island, Aceh Province, Indonesia
}

\author{
EDWIN SETIAWAN", FARID KAMAL MUZAKI, AWIK P.D. NURHAYATI, NOVA MAULIDINA \\ Department of Biology, Faculty of Science, Institut Teknologi Sepuluh Nopember. Jl. Raya ITS, Keputih, Sukolilo, Surabaya 60111, East Java, \\ Indonesia. Tel.: +62-31-596 3857, Fax.: +62-31-596 3857, `email: edwin@ bio.its.ac.id
}

Manuscript received: 7 December 2018. Revision accepted: 19 October 2019

\begin{abstract}
Setiawan E, Muzaki FK, Nurhayati APD, Maulidina N. 2019. Record of shallow-water sponges in Simeulue Island, Aceh Province, Indonesia. Biodiversitas 20: 3246-3257. The first and present study on shallow water sponges in Simeulue islands, Aceh Province, Indonesia recorded more than twenty species of marine sponges. This first assessment was also part of Ekpedisi Widya Nusantara X (E-WINN X) coastal chapter 2017 where was conducted in Simeulue islands, Aceh. Most of the recorded sponges are common species that are also recognized inhabiting a broad distribution in the West Indo-Pacific marine ecoregion. All recorded shallow-water sponges are Demospongian sponges. Among the three selected types of shallow water sponge habitats, a number of sponges are achieved mostly in shallow reefs in comparison to sandy and mangrove lagoons. The current study on species recorded also documents general characteristic enriches and highlights the importance of filling the gaps in distributional patterns of sponges on the west coast of Sumatra.
\end{abstract}

Keywords: Aceh, coastal chapter, E-WINN X, first record, Indonesia, shallow water habitat, Simeulue Island, sponges

\section{INTRODUCTION}

Simeulue Island is an island that is situated in the Indian Ocean and a part of Aceh province, Indonesia. Simeulue Island also has a unique hydrology condition, for example, marshes and estuaries, short and shallow rivers and small lakes. Geologically, Simeulue Island lies on the western coast of Sumatra, which is a tip of the Eurasian zone or called a Sunda plate or Sundaland. Formation of the Sunda plate ended in the Pliocene era or about 5 million years ago. Furthermore, in Pleistocene or two million years ago, Western Sumatra experienced a decline in water levels from $110-150 \mathrm{~m}$ from the current condition and returned to current water levels in Holocene or 11700 years ago. Because of these extremes, sea level gradation formed over a long time resulted in differences of marine biota among west coast of Sumatra to other regions of Indonesia (Hoeksema 2007). Moreover, genetic diversity on marine biota at the western coastal fauna of Sumatra possesses a uniform characteristic to fauna in the Malay Peninsula, Kalimantan and Java (Barber and Bellwood 2005; Kochzius and Nuryanto 2008; Kochzius et al. 2009; Timm et al. 2012).

There has not been any record on marine fauna that collected from this area and therefore, in 2017, Research Center of Oceanography (P2O), Indonesian Institute of Sciences (LIPI) launched an expedition for exploring shallow marine fauna diversity called Coastal Chapter of Ekspedisi Widya Nusantara X (E-WIN X) from 24-30 July 2017. In this record, we describe shallow-water sponges (Phylum Porifera Grant, 1836). In general, sponges have been understood for having several roles in marine ecosystems because of their effectiveness as filter feeders, unique symbiotic living with cyanobacteria, and support on reef e.g., Diaz and Rutzler (2001). Ecologically, sponges also act as a bio-eroder for coral restoration, particularly shallow-water sponges, a recycler of chemical elements in the ocean, a host of symbiotic organisms such as dinoflagellates (Bell 2008), and supporting biota for coral survival (de Goeij et al. 2013).

\section{MATERIALS AND METHODS}

\section{Sampling area}

The research began with sampling activities and sample preparation in Simeulue Island from July 24, 2017, until July 30, 2017. Snorkeling and random collecting methods were used for exploring shallow-water sponges on 100meter length along the coastline with a maximum depth of $5 \mathrm{~m}$. Six spots have been chosen (Figure 1 and Table 1). In addition, lifeforms or in-situ and ex-situ sponges' samples e.g., color in life before collected, possessing a branching or encrusting form, and attach on which substrate like sandy, ruble coral, or hard substrate were documented for aiding sponges' identification.

\section{Spicules, skeleton slides preparation and identification}

Sponges that have been sampled from those six locations were rinsed two times and preserved in 96\% ethanol. In the identification stages, each of approximately $\pm 10 \mathrm{~cm}^{3}$ sponges was divided into two parts. A small piece of specimen measuring $\pm 4 \mathrm{~cm}^{3}$ was immersed in a bleach solution (Clorox.), and after sponging tissue in the skeleton was completely removed by bleach solution, the spicules settled down. 


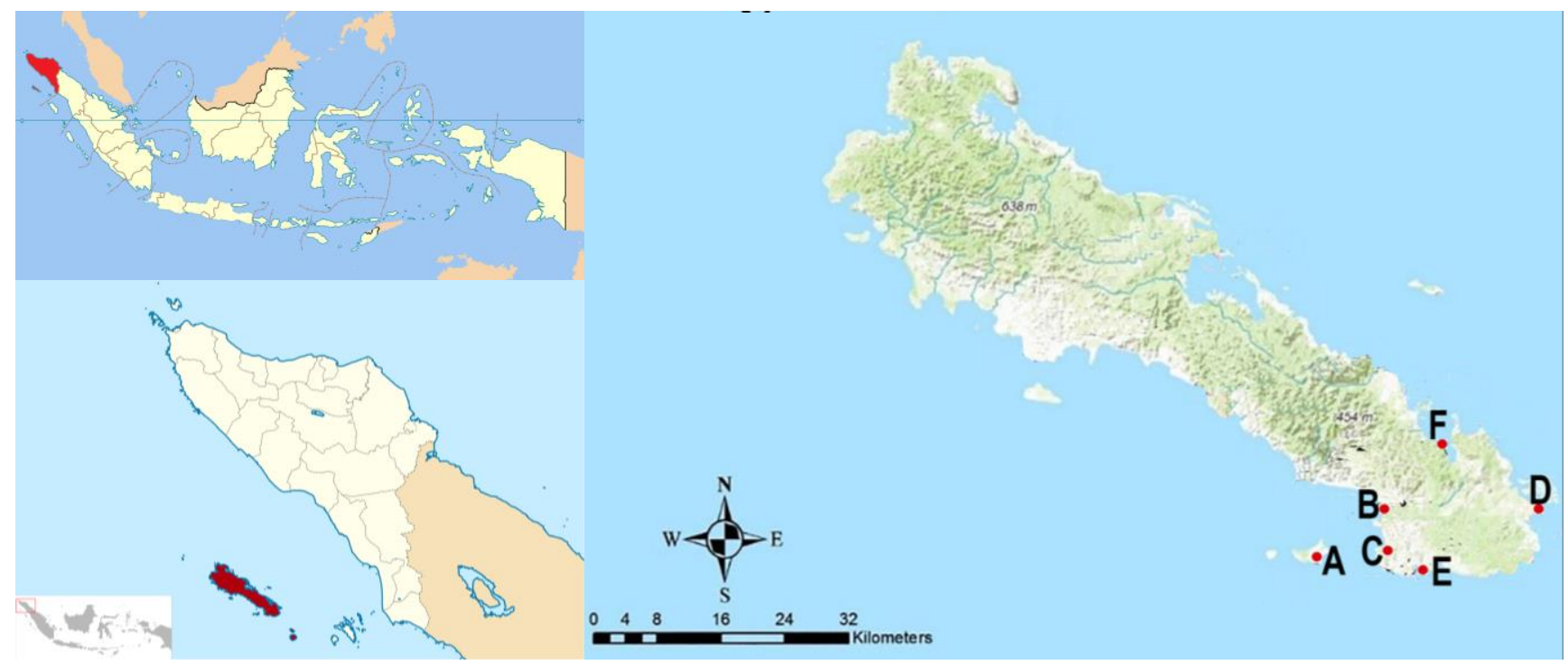

Figure 1. Sampling location of Simeulue Island, Aceh Province, Indonesia. Note: See Table 1 for sampling point coordinates

Table 1. Localities and GPS locations of sampling points

\begin{tabular}{clll}
\hline Sampling point & Localities & GPS coordinates & Habitat \\
\hline A & Pulau Tepah & $2^{\circ} 21^{\prime} 20.3 \mathrm{~N} 96^{\circ} 15^{\prime} 22.9 \mathrm{E}$ & Shallow reefs \\
$\mathrm{B}$ & Ulul Umang & $2^{\circ} 25^{\prime} 1.92 \mathrm{~N} 96^{\circ} 29^{\prime} 3.013 \mathrm{E}$ & Shallow sandy lagoon \\
$\mathrm{C}$ & Labuhan Bakti & $2^{\circ} 24^{\prime} 4.49 \mathrm{~N} 96^{\circ} 28^{\prime} 36.97 \mathrm{E}$ & Shallow sandy lagoon \\
$\mathrm{D}$ & Bengkala Island & $2^{\circ} 23^{\prime} 56.2 \mathrm{~N} 96^{\circ} 28^{\prime} 32.8 \mathrm{E}$ & Mangrove lagoon \\
$\mathrm{E}$ & Port Busung & $2^{\circ} 23^{\prime} 15.4 \mathrm{~N} 96^{\circ} 20^{\prime} 08.9 \mathrm{E}$ & Shallow reefs \\
$\mathrm{F}$ & Teluk Dalam & $2^{\circ} 38^{\prime} 56.03 \mathrm{~N} 96^{\circ} 11^{\prime} 0.1796 \mathrm{E}$ & Mangrove lagoon \\
\hline
\end{tabular}

Furthermore, the spicule solution was rinsed three times with distilled water $5 \mathrm{x}$ to eliminate Clorox and finally preserved in $70 \%$ ethanol. Spicules were mounted on the object-glass, covered with glued coverslip and furthermore observed under a light microscope. While the second large sections of $\pm 6 \mathrm{~cm}^{3}$ were cross-sectioned and longitudinally cut with a hand-cutting knife and sliced into a size of an approximate 30- $200 \mu \mathrm{m}$ for skeletons observations and followed by mounting on slides and observed under light microscope, which is similar protocol to spicule observation before. Moreover, self-made spicule and skeleton slides were observed to distinguish their genus or species identity using a sponge identification manual from (Hooper and van Soest 2002) and official website for Porifera database from World Porifera Database (WPD) http: //www.marinespecies.org/porifera/ (van Soest et al. 2018).

\section{RESULTS AND DISCUSSION}

\section{Results}

Thirty-eight specimens were able to be collected from five sampling locations (See Figure 1 and Table 1). Furthermore, 18 genera were able to be delimited from those 38 specimens. Moreover, 14 species were able to be identified among those 18 genera.
Systematics according to World Porifera Database (WPD) http: //www.marinespecies.org/porifera/ (van Soest et al. 2018).

Phylum : Porifera Grant, 1836

Class : : Demospongia Sollas, 1885

Subclass : Keratosa Grant, 1861

Order : : Dictyoceratida Minchin, 1900

Family : Thorectidae Bergquist, 1978

Subfamily : Thorectinae Bergquist, 1978

Genus : Hyrtios Duchassaing \& Michelotti, 1864

Species : Hyrtios erectus (Keller, 1889)

\section{Hyrtios erectus}

Material examined: Four ex, field code 2017_SIM01_002, 2017_SIM01_007, 2017_SIM01_010 (Pulau Tepah, sampling point A) and 2017_SIM02_002 (Ulul Umang, sampling point B).

Descriptions: Four specimens shown a form of a rounded ball and possess a thick encrusting form. In living form, it had a dark and black color and changed into pale black in ethanol. A distinctive character on the surface is sharp conuli form in connection with four of five networks and sticky mucus. Oscules also naturally scattered in the surface (Figure 2.A). 
Skeleton: Spongin fiber is stout despite a connection among the sponging is not very tight. However, due to the presence of stout sponging fiber, the consistency of these sponges is compact and difficult to be a tear or sliced (Figure 2.A-B).

Remarks: Currently, this species is considered as having cryptic speciation. Erpenbeck et al. (2017) reported based on morpho-molecular analysis, other Hyrtios erectus with the rounded ball should be differentiated with Hyrtios erectus form in our specimen.

Habitat: Shallow reefs that possessed by A locality in addition to shallow sandy lagoons for B locality

Genus : : Dactylospongia Bergquist, 1965

Species : : Dactylospongia elegans (Thiele, 1899)

\section{Dactylospongia elegans}

Material examined: One ex, field code 2017_SIM02_006 (Ulul Umang, sampling point B).

Descriptions: Sponges that possess slimy and yellowbrownish live color (Figure 3.A) and turn into whitishyellow in ethanol. Papillae structures are visible despite unclear oscules on its surface.

Skeleton: Spongin fibers are thick and form a round mesh (Figure 3.B-C).

Habitat: Shallow sandy lagoons in B sampling location.

$\begin{array}{lll}\text { Subfamily } & : \text { Phyllospongiinae Keller, } 1889 \\ \text { Genus } & : \text { Phyllospongia } \text { Ehlers, } 1870 \\ \text { Species } & : \text { Carteriospongia foliascens } & \text { (Pallas, } \\ \text { 766) } & & \end{array}$

\section{Carteriospongia foliascens}

Material examined: Three ex, field code 2017_SIM02_007 (Ulul Umang, sampling point B),
2017_SIM03_005, and 2017_SIM03_007 (Labuhan Bakti, sampling point $\mathrm{C}$ )

Descriptions: Sponges that possess a structure like a whorled or curved plate or sheet. On its surface, nodules are recognized and scattered. Oscules 1-2 mm, on only one face of the blade. Sponges have a flexible, fibrous, tears easily consistency. Live color is yellow whitish or creamy (Figure 4.A) and turns pale white in ethanol.

Skeleton: Foreign debris is incorporated within a less compacted structure of spongin fibers connection (Figure 4.B-C).

Habitat: Shallow sandy lagoons that are possessed by those B and C sampling point's locality.

$\begin{array}{ll}\text { Genus } & : \text { Lendenfeldia Bergquist, } 1980 \\ \text { Species } & : \text { Lendenfeldia dendyi (Lendenfeld, 1889) }\end{array}$

\section{Lendenfeldia dendyi}

Material examined: one ex, field code 2017_SIM02_010 (Ulul Umang, sampling point B).

Descriptions: Sponges that possess a flower and meandriform lamella. The small conuli form is present on its surface without any oscules. Live color is green (Figure 5.A) and turns to white greenish in ethanol. Sponges also possess hard and incompressible consistency.

Skeleton: Very irregular network is present with a fragment of broken spicules present (Figure 5.B-C)

Habitat: Shallow sandy lagoons that possessed by $\mathrm{B}$ locality

Family : : Irciniidae Gray, 1867

Genus : : Ircinia Nardo, 1833

Species : Ircinia ramosa (Keller, 1889)

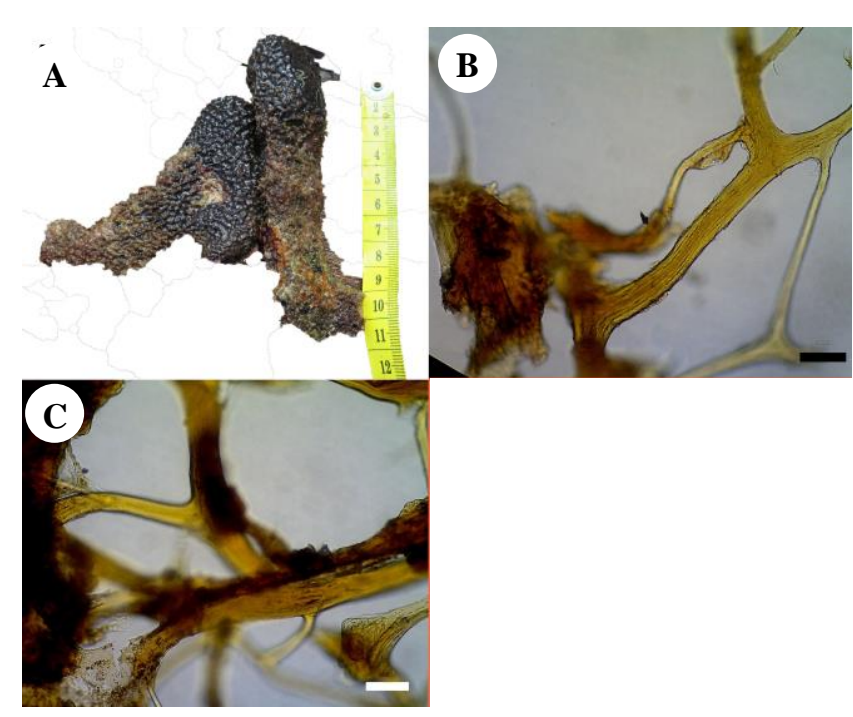

Figure 2.A. Lifeform ex number 2017_SIM01_002, B, Perpendicular section 40x C, Tangential section 40x. B and C scales $100 \mu \mathrm{m}$

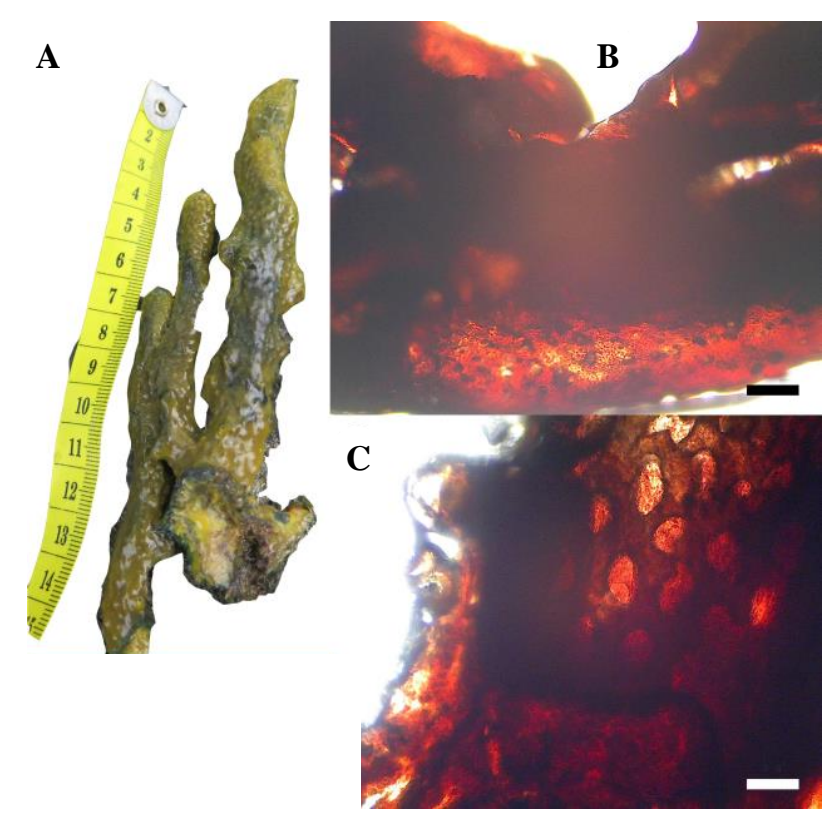

Figure 3.A. Lifeform ex number 2017_SIM02_006, B, Perpendicular section 40x C, Tangential section 40x. B and C scales $100 \mu \mathrm{m}$ 


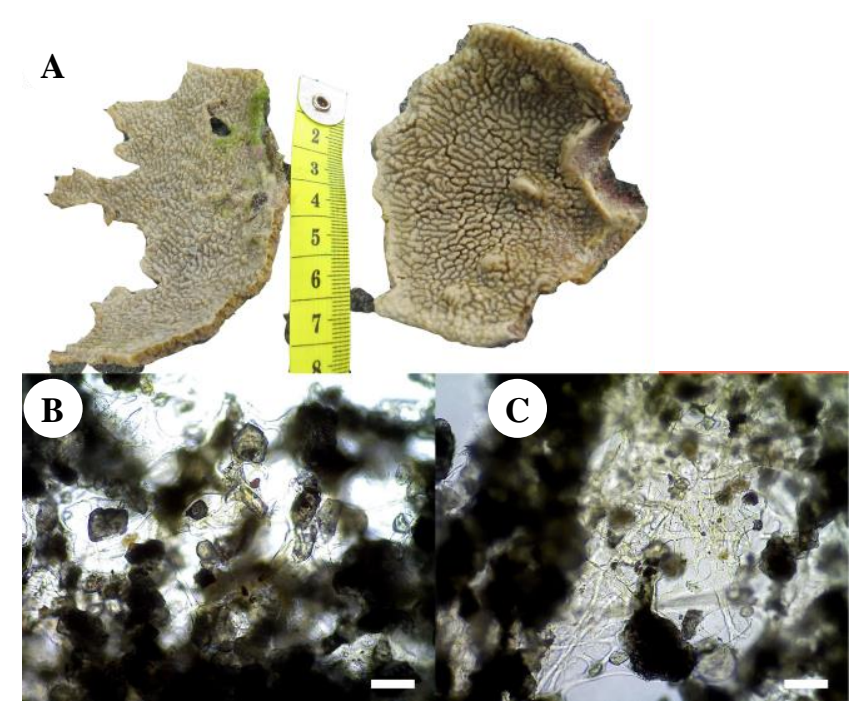

Figure 4.A. Lifeform ex number 2017_SIM02_007, B, Perpendicular section 40x C, Tangential section 40x. B and C scales $100 \mu \mathrm{m}$

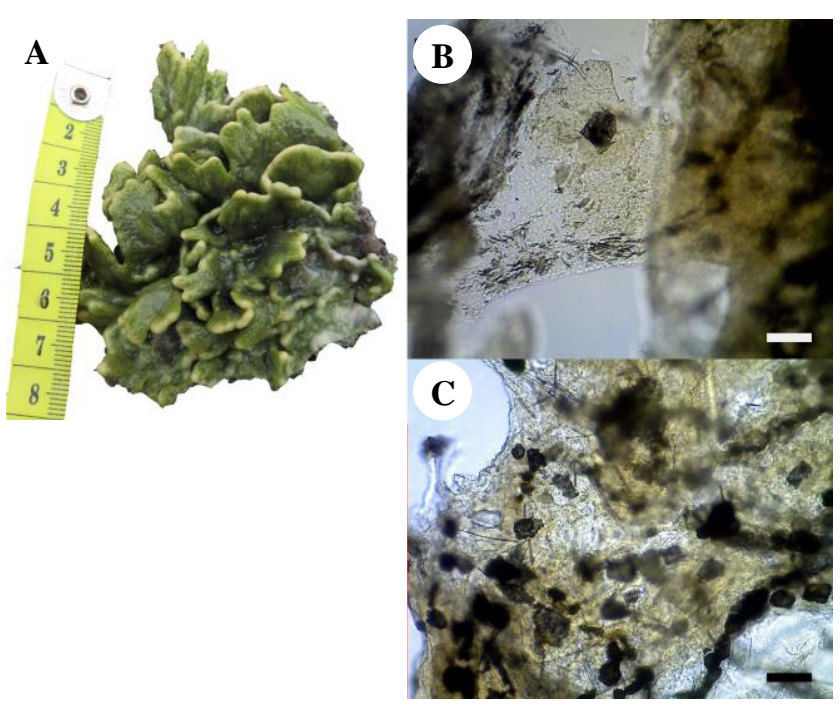

Figure 5.A. Lifeform ex number 2017_SIM02_010, B, Perpendicular section 40x C, Tangential section 40x. B and C scales $100 \mu \mathrm{m}$

\section{Ircinia ramosa}

Material examined: Seven ex, field code 2017_SIM01_003, 2017_SIM01_004, 2017_SIM01_005, 2017_SIM01_011, 2017_SIM01_013 (Pulau Tepah, sampling point A), 2017_SIM02_001 (Ulul Umang, sampling point B), 2017_SIM05_001 (Busung beach, sampling point $\mathrm{E}$ )

Descriptions: Sponges that possess a structure like an elongated branched with green or brown ferruginous color (Figure 6.A) and turn into yellow clay in ethanol. On its surface, conuli are recognized and scattered including obvious oscules.

Skeleton: Thick primary sponging fibers are seen in the middle which made sponges possess hard and tough consistency (Figure 6.B-C).

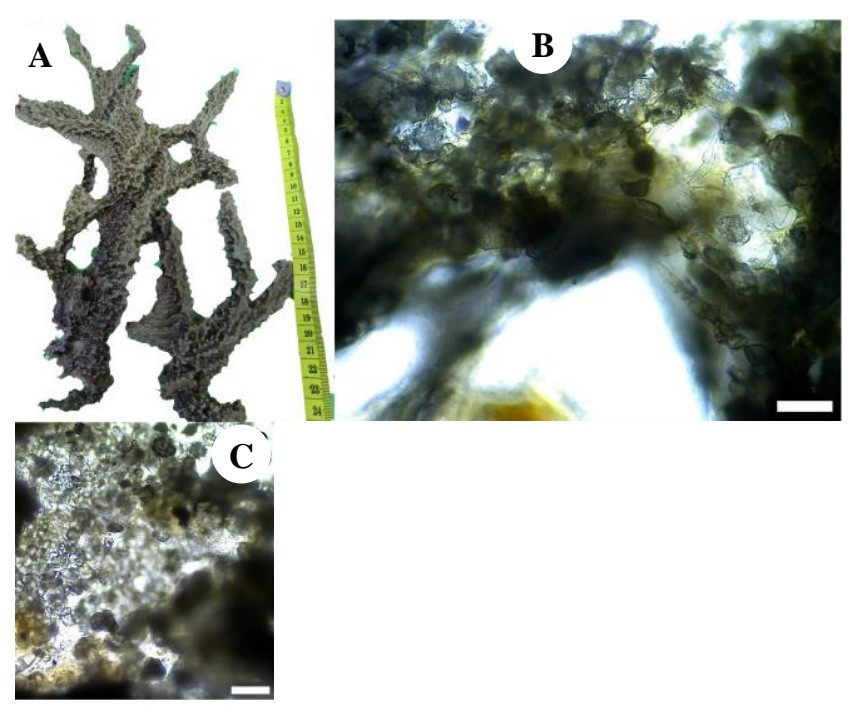

Figure 6.A. Lifeform ex number 2017_SIM01_011, B, Perpendicular section 40x C, Tangential section 40x. B and C scales $100 \mu \mathrm{m}$

Habitat: Shallow reefs that are possessed by those A, E sampling point's locality in addition to shallow sandy lagoons for B locality.

Family : Dysideidae Gray, 1867

Genus : Lamellodysidea Cook \& Bergquist, 2002

Species : Lamellodysidea chlorea (de Laubenfels, 1954)

\section{Lamellodysidea chlorea}

Material examined: two ex, field code 2017_SIM02_009 (Ulul Umang, sampling point B), 2017_SIM03_004 (Labuhan Bakti, sampling point C)

Descriptions: Ramose sponges with a simple branching finger form and possesses yellow-greenish and pale color with soft spongy consistency (Figure 7.A). This sponge also possesses a lipostomus structure, in which oscules and pores are closed to each other in its surface in addition to conulose surface. The general structure is thin and fleshy dermis.

Skeleton: This sponge possesses a reticulation structure with debris-filled fibers (Figure 7.B-C).

Habitat: Shallow sandy lagoons that possessed by B locality in addition to shallow reefs E locality.

Species : Lamellodysidea herbacea (Keller, 1889)

\section{Lamellodysidea herbacea}

Material examined: one ex, field code 2017_SIM05_002 (Busung beach, sampling point E).

Descriptions: Branching sponges with predominantly form dichotomy. Branches form a roll and a leaf. Live color of this sponges is grey-brown (Figure 8.A) and changes to pale grey in ethanol. Conuli structures are present in its surface, in addition, a low amount of osculum that is small and forms a cross.

Skeleton: This sponge possesses a pale yellow color, tender, and elastic spongin fiber. Reticulation structure of sponges is formed like a barrel with a long axis and sometimes sharp axis (Figure 8.B-C).

Habitat: Shallow reefs that possessed by E locality. 
$\mathbf{A}$

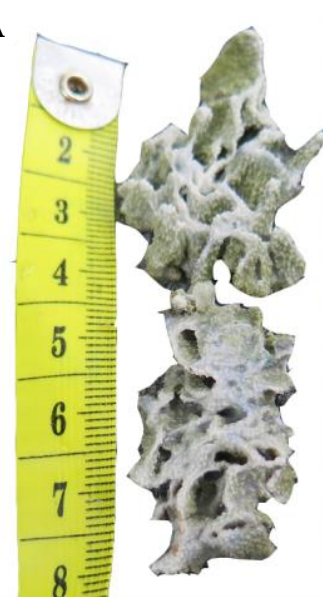

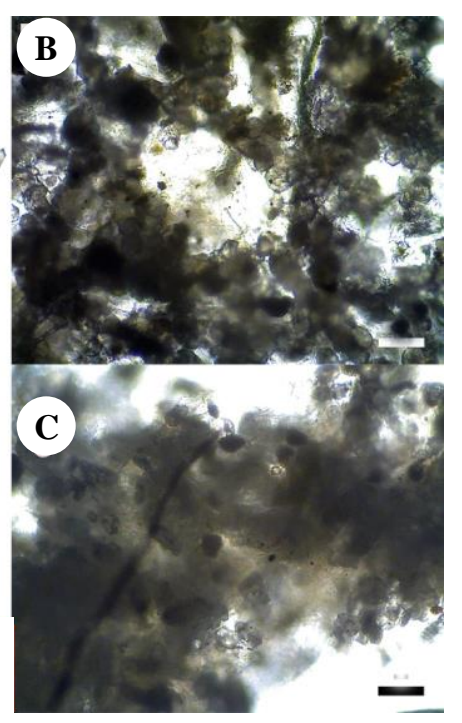

Figure 7.A. Lifeform ex number 2017_SIM02_009, B, Perpendicular section 40x C, Tangential section 40x. B and C scales $100 \mu \mathrm{m}$

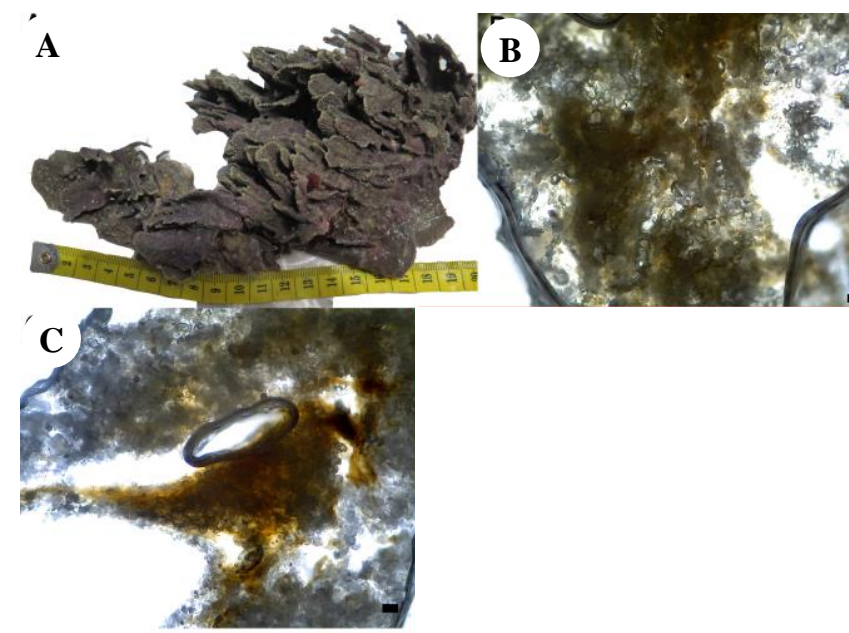

Figure 8.A. Lifeform ex number 2017_SIM05_002, B, Perpendicular section 40x C, Tangential section 40x. B and C scales $100 \mu \mathrm{m}$
Genus
: Dysidea Johnston, 1842
Species
: Dysidea sp.

\section{Dysidea sp.}

Material examined: one ex, field code 2017_SIM06_005 (Teluk Dalam, sampling point F).

Descriptions: Sponges that attach to the root of mangrove and possess a regular surface. Live color is gray (Figure 9.A) and turn white in ethanol. Sponges' consistency is fragile.

Skeleton: Consist of irregular reticulation and filled with foreign particles mainly sands (Figure 9.B-C).

Habitat: Mangrove lagoon that possessed by F locality.

Family : : Spongiidae Gray, 1867

Genus : Coscinoderma Carter, 1883

Species : Coscinoderma $\mathrm{sp.}$
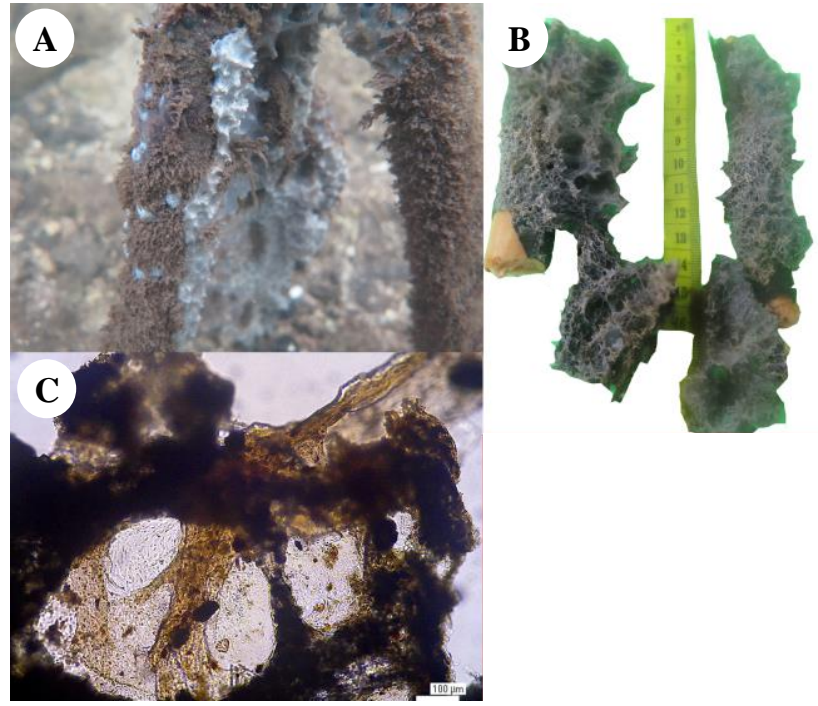

Figure 9.A. Lifeform ex number 2017_SIM06_005, B, Perpendicular section 40x C, Tangential section 40x. B and C scales $100 \mu \mathrm{m}$

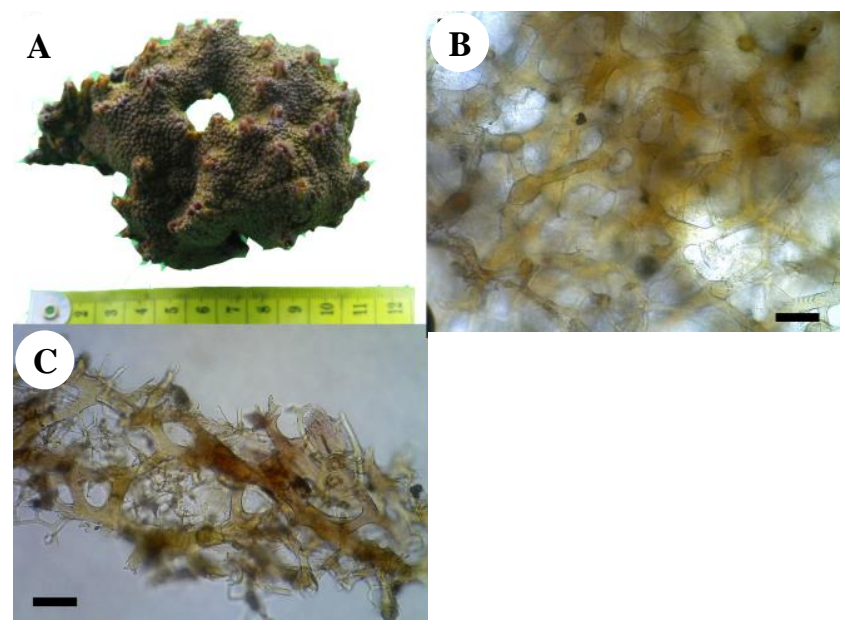

Figure 10.A. Lifeform ex number 2017_SIM01_014, B, Perpendicular section 40x C, Tangential section 40x. B and C scales $100 \mu \mathrm{m}$

\section{Coscinoderma sp.}

Material examined: one ex, field code 2017_SIM01_014 (Pulau Tepah, sampling point A).

Descriptions: Battledore or rocket-shaped sponges with an obvious denticulate structure on its surface in addition to conuli structure. The sponge has hard incompressible consistency and brown, yellow color in life (Figure10.A).

Skeleton: Primary fibers are stout with obvious whorl structure on its secondary fiber (Figure 10.B-C).

Habitat: Shallow reefs that possessed by A locality.

Subclass : Heteroscleromorpha Cárdenas, Pérez \& Boury-Esnault, 2012

Order : Bubarida Morrow \& Cárdenas, 2015 1990

Family : Dictyonellidae van Soest, Diaz \& Pomponi, 
Subfamily : Thorectinae Bergquist, 1978

Genus : : Acanthella Schmidt, 1862

Species : : Acanthella cavernosa Dendy, 1922

\section{Acanthella cavernosa}

Material examined: one ex, field code 2017_SIM01_001 (Pulau Tepah, sampling point A).

Descriptions: Sponges that possess lobose form. The surface of sponges consists of suculetions forms that are blunt. The color of sponges is orange (Figure 11.A) and turn into pale orange in ethanol.

Skeleton : Skeleton forms treelike and its branches possess very stout fiber. In addition, a very dense network of slender spicules is also present (Figure 11.B-C).

Spicules : Spicules consist of two forms, which are slender style (Figure 11.D) (261.9-367.2-712 x 5.7-9.1$14.5 \mu \mathrm{m})$ and slender strongyle (Figure 11.E) (240.7-467.6796.8 x 3.3-6-9.2 $\mu \mathrm{m}$ )

Habitat: Shallow reefs that possessed by A locality

$\begin{array}{ll}\text { Order } & \text { : Biemnida Morrow, 2013 } \\ \text { Family } & \text { : Biemnidae Hentschel, 1923 } \\ \text { Genus } & \text { : Biemna Gray, 1867 } \\ \text { Species } & \text { : Biemna fortis (Topsent, 1897) }\end{array}$

\section{Biemna fortis}

Material examined: three ex, field code 2017_SIM03_002 (Labuhan Bakti, sampling point C), 2017_SIM04_002 (Bengkala, sampling point D) and 2017_SIM06_006 (Teluk Dalam, sampling point F).

Descriptions: Massive sponge that possesses a spongy, firm and fibrous consistency in addition to an encrusting growth with upper branch (Figure 12.A). In life, it has a white-grey color.

Skeleton : Sponge possesses dense irregular reticulation (Figure 12.B-C).

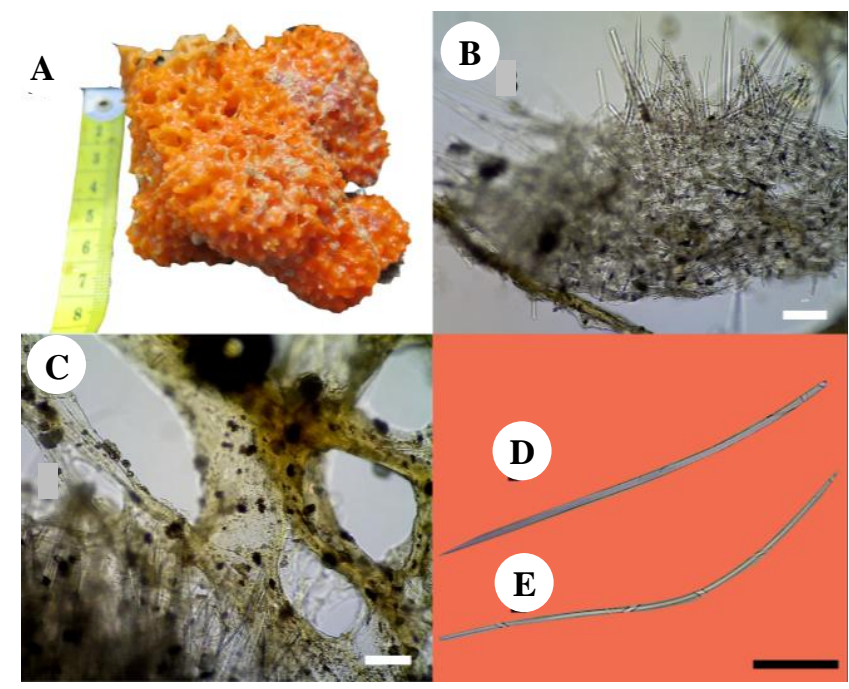

Figure 11.A. Lifeform ex number 2017_SIM01_001, B, Perpendicular section 40x C, Tangential section 40x. D. Slender style spicule 100x. E. Slender strongyle spicule 100x. B, C, D and E scales $100 \mu \mathrm{m}$
Spicules : Spicules consist of three forms, which are styles (Figure 12.F) (582-860.9-1132 x 18.5-23.1-28.8 $\mu \mathrm{m})$, three classes' sigma (Figure 12.D) (15.8-21.2-27.3 $\mu \mathrm{m}, 34.5-45.2-67.6 \mu \mathrm{m}$ and 73.6-94.7-129.3 $\mu \mathrm{m})$, rhapides (Figure 12.E) (111.6-152.7-185.9 $\mu \mathrm{m})$ for 2017_SIM03_002. Furthermore, for 2017_SIM04_002, spicules composition is styles (785-1070.2-1135.6 x 8.919.5-30.8 $\mu \mathrm{m})$, three classes' sigma (14-21.6-27.7 $\mu \mathrm{m}$, 30.4-36.8-50.3 $\mu \mathrm{m}$ and 83.7-98.7-117.6 $\mu \mathrm{m})$, rhapides (139.5-178.2-277.4 $\mu \mathrm{m})$. Moreover, only styles (654.4774.57-929.8 $\mathrm{x}$ 16.3-20-25.8 $\mu \mathrm{m})$ are recognized in 2017_SIM06_006

Habitat: Shallow sandy lagoons that possessed by $\mathrm{C}$ locality and mangrove lagoons that are possess by $\mathrm{D}$ and $\mathrm{F}$ locality.

$\begin{array}{ll}\text { Order } & \text { : Clionaida Morrow \& Cárdenas, } 2015 \\ \text { Family } & \text { : Clionaidae d'Orbigny, 1851 } \\ \text { Genus } & \text { : Spheciospongia Marshall, 1892 } \\ \text { Species } & \text { : Spheciospongia inconstans (Dendy, 1887) }\end{array}$

\section{Spheciospongia inconstans}

Material examined: one ex, field code 2017_SIM03_003 (Labuhan Bakti, sampling point C)

Descriptions: Encrusting sponge that buried on sandy lagoon possesses a hard consistency. The color of sponges is purple-brown (Figure 13.A), which turns white in ethanol. Conspicuous oscules are easy to be recognized in addition to green zooxanthellae on the skeleton.

Skeleton : Numerous robust spicules that form a dense network are recognized in its ectosome and spicules also scattered densely in its choanosome in addition, green zooxanthellae are recognized on the skeleton. Skeleton form has numerous robust spicules that form a dense network in its ectosome, and the spicules also scattered densely in its choanosome (Figure 13.B-C)

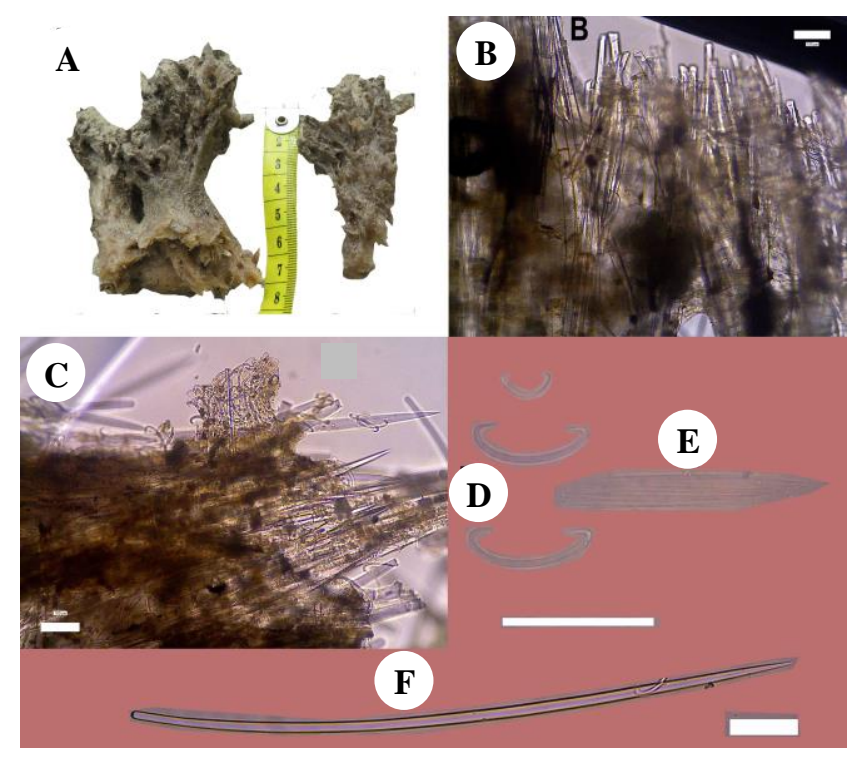

Figure 12.A. Lifeform ex number 2017_SIM03_002, B, Perpendicular section 40x C, Tangential section 40x. D. Three classes sigma spicule 100x. E. Rapides spicule 100x. F. Styles spicule. B, C, D, E, and F scales $100 \mu \mathrm{m}$ 


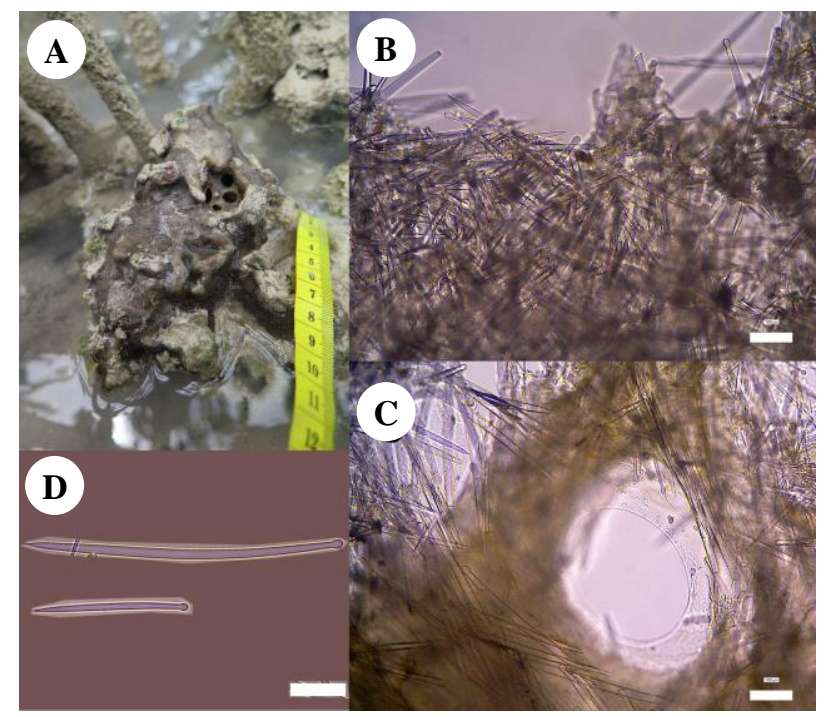

Figure 13.A. Lifeform ex number 2017_SIM03_003, B, Perpendicular section 40x C, Tangential section 40x. D. Tylostyles spicule 100x. B, C, and D scales $100 \mu \mathrm{m}$

Spicules: Spicules consist of tylostlyes (Figure 13.D) (357-542.7-730.7 x 15-20-24 $\mu \mathrm{m})$

Habitat: Shallow sandy lagoons that possessed by $\mathrm{C}$ locality.

$\begin{array}{ll}\text { Order } & : \text { Tetractinellida Marshall, 1876 } \\ \text { Suborder } & \text { : Spirophorina Bergquist \& Hogg, } 1969 \\ \text { Family } & : \text { Tetillidae Sollas, 1886 } \\ \text { Genus } & : \text { Paratetilla Dendy, 1905 } \\ \text { Species } & \text { : Paratetilla aruensis } \text { Hentschel, } 1912\end{array}$

\section{Paratetilla aruensis}

Material examined: two ex, field code 2017_SIM05_009 and 2017_SIM05_010 (Busung beach, sampling point $\mathrm{E}$ )

Descriptions: Ball or pear sponges that a hard and stout consistency. The color of sponges is yellow-orange (Figure 14.A), which turns pale orange in ethanol. There is a stalk in addition to a petal forms bellow sponges. The surface is rough. Oscules are not clearly seen.

Skeleton : Tight and dense of long and slender spicules composition in addition to stout sponging fibers (Figure 14.B).

Spicules : Spicules consist long and slender oxeas amphioxi form, (1105-1512.2-2011 x 11-19.2-26.5 $\mu \mathrm{m})$ (Figure 14.C) and spherasters (261-377.3-504 $\mu \mathrm{m})$

Habitat: Shallow reefs that possess by E locality

$\begin{array}{ll}\text { Order } & \text { : Haplosclerida Topsent, 1928 } \\ \text { Family } & \text { : Phloeodictyidae Carter, 1882 } \\ \text { Genus } & \text { : Oceanapia Norman, 1869 } \\ \text { Species } & \text { : Oceanapia fistulosa (Bowerbank, 1873) }\end{array}$

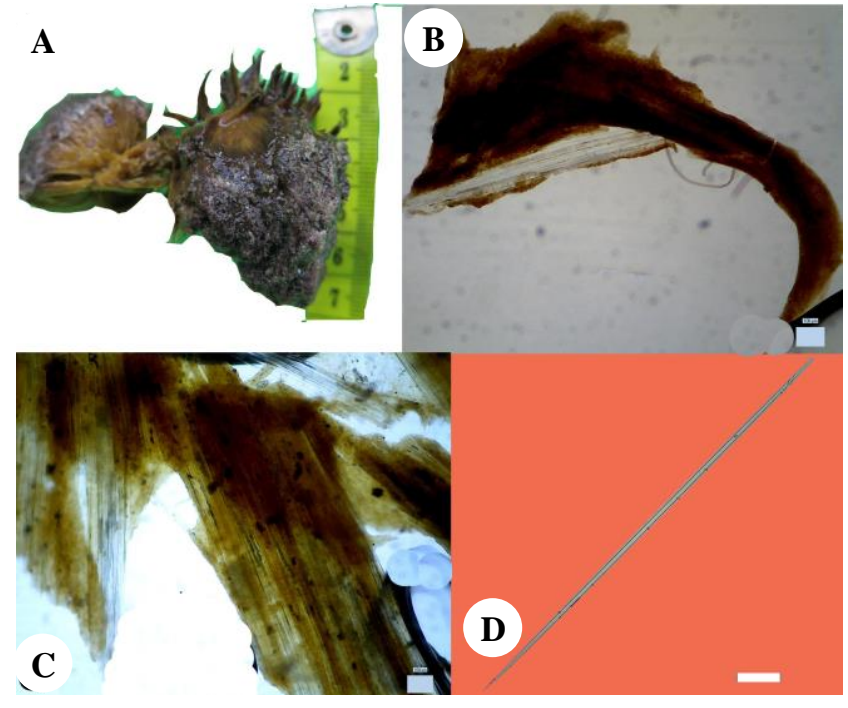

Figure 14.A. Lifeform ex number 2017_SIM05_009, B, Perpendicular section 40x C, Tangential section 40x. D. Slender oxeas amphioxi spicule 100x. B, C, and D scales $100 \mu \mathrm{m}$

\section{Oceanapia fistulosa}

Material examined: two ex, field code 2017_SIM05_008 (Busung beach, sampling point E) and 2017_SIM06_004 (Teluk Dalam, sampling point F)

Descriptions: Massive sponges that possess long, slender and fistulous structures. The surface of sponges is smooth, pores and osculum are inconspicuous (Figure 15.A). the First specimen is attached and grow into rubble coral because it inhabits shallow reef, whereas the second specimen is attached into other sponges that identified as Dysidea sp and inhabit in mangrove lagoon that possess a muddy substrate and turbid water. Both specimens possess violet color in life and turn into whitish violet in ethanol.

Skeleton : Sponges possess fibrous and stout, elongate diffused reticulation (Figure 15.B-C)

Spicules : Oxeas (Figure 15.D) with dimension of 416-497.3-619.8 x 7.3-11.4-18.1 $\mu \mathrm{m}$ for first specimen and 359.9-419.6-461.2 x 10.1-12.9-15.8 $\mu \mathrm{m}$ second specimens

Habitat: Shallow reefs that possessed by E locality and mangrove lagoon by $\mathrm{F}$ locality.

$\begin{array}{ll}\text { Family } & \text { : Petrosiidae van Soest, 1980 } \\ \text { Genus } & : \text { Petrosia } \text { Vosmaer, 1885 } \\ \text { Subgenus } & : \text { Petrosia (Strongylophora) Dendy, } 1905 \\ \text { Species } & : \text { Petrosia (Strongylophora) corticata }\end{array}$
(Wilson, 1925)

\section{Petrosia (Strongylophora) corticata}

Material examined: one ex, field code 2017_SIM01_008 (Pulau Tepah, sampling point A)

Descriptions: Sponges that form roller and undulates smooth branches. Surface possess like parchment structure and oscula with sieve-form is conspicuous. Slimy brown mucous present when sponges are sliced because of pulpy structure inside (Figure 16.A). 
Skeleton : paucispicular reticulation of the larger spicules forming irregular triangular meshes on ectosome in addition to perpendicular tufts of the intermediate spicules, On the other hand, subectosomal tracts form regular polygonal meshes, with larger spicules. Moreover, choanosomal skeleton is dense consists of many spicules that are scattered loosely and singly (Figure 16.B-C).

Spicules : Two types of strongyloxeas (Figure 16.D) with dimension of 43.2-109.-184.6 x 4-7.4-11 $\mu \mathrm{m}$ and 201 -227.6-270 x 5.5-8.5-12.6 $\mu \mathrm{m}$

Habitat: Shallow reefs that possessed by A locality

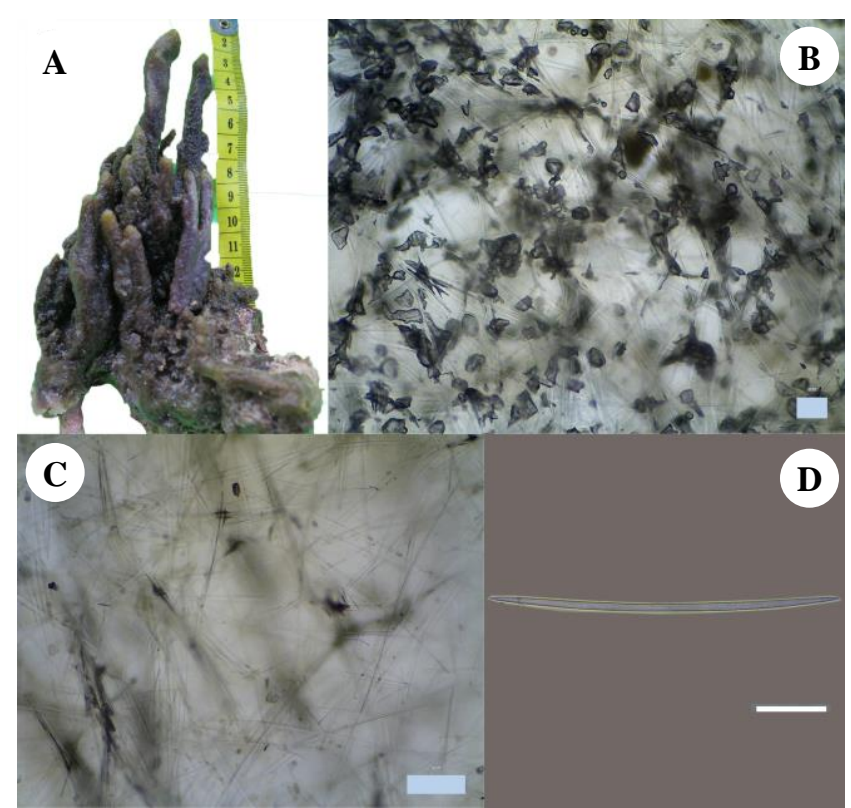

Figure 15.A. Lifeform ex number 2017_SIM05_008, B, Perpendicular section 40x C, Tangential section 40x. D. Oxeas amphioxi spicule 100x. B, C, and D scales $100 \mu \mathrm{m}$

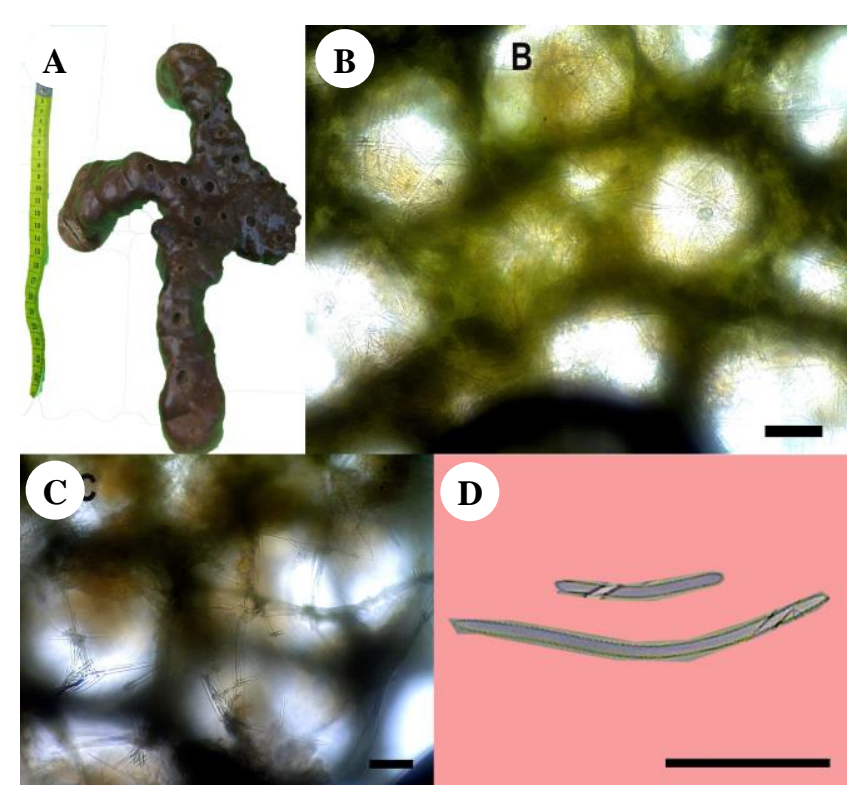

Figure 16.A. Lifeform ex number 2017_SIM01_008, B, Perpendicular section 40x C, Tangential section 40x. D. Strongylooxeas spicule 100x. B, C, and D scales $100 \mu \mathrm{m}$
Family
Genus
: Petrosiidae van Soest, 1980
Subgenus
Species
Species : Petrosia (Petrosia) nigricans Lindgren, 1897

\section{Petrosia (Petrosia) nigricans}

Material examined: one ex, field code 2017_SIM01_009 (Pulau Tepah, sampling point A)

Description: Black color and broadly tubular sponges in which outside surface is undulated or irregularly sharply ridged, almost honeycombed, while the inner side is smooth (Figure 17.A). In ethanol, sponges change into more pale black color. Oscules are not very obvious, and slime is exuded

Skeleton : The ectosomal skeleton is a tangential reticulation of bundles and brushes consist of 6-8 spicules (Figure 17.B-C). Choanosomal skeleton is a system of thick spicule tracts forming large almost rectangular meshes, and spongin is not visible. Pigment grains are present in the choanosomal layer, but not as abundant in the ectosomal layer.

Spicules : Strongyloxeas with dimension of 165.1177.1-187.5 x 5.9-7.9-10.5 $\mu \mathrm{m}$

Habitat: Shallow reefs that possessed by A locality

$\begin{array}{ll}\text { Genus } & : \text { Petrosia } \text { Vosmaer, } 1885 \\ \text { Subgenus } & : \text { Petrosia }(\text { Petrosia) Vosmaer, } 1885 \\ \text { Species } & : \text { Petrosia }(\text { Petrosia) } \mathrm{sp} .\end{array}$

\section{Petrosia (Petrosia) sp.}

Material examined: five ex, field code 2017_SIM05_003，2017_SIM05_004，2017_SIM05_005, 2017_SIM05_006, 2017_SIM05_007 (Busung Beach, sampling point E).

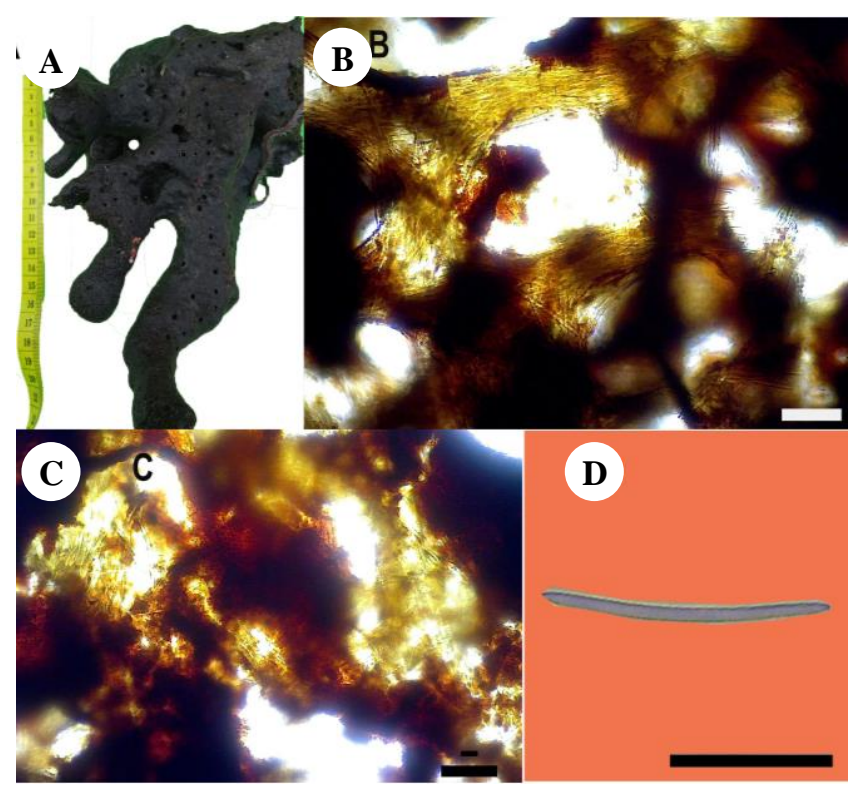

Figure 17.A. Lifeform ex number 2017_SIM01_009, B, Perpendicular section 40x C, Tangential section 40x. D. Strongylooxeas spicule 100x. B, C, and D scales $100 \mu \mathrm{m}$ 
Description: Specimen 2017_SIM04_003 possesses a violet color in life and turn into violet pale in ethanol. Oscules are clearly seen in surface and this sponge possesses a hard woody consistency. Specimen 2017_SIM05_004 possesses an orange color in life and turns into pale orange in ethanol. Oscules are also clearly seen in this sponge. However, this specimen possesses an elastic consistency, in which dissimilar into 2017_SIM04_003 specimen. Specimen 2017_SIM05_005 possesses a violet color in life and turns into pale violet in ethanol. Oscules are not conspicuous. This sponge possesses a hard with crumble consistency, similar to specimens 2017_SIM05_006 and 2017_SIM05_007 (Figure 18).

Skeleton : Five specimens possess a characteristic isotropic skeleton, cored with 2 until 3 unispicular spicules.

Spicules : Oxeas with dimension of 103.9-118.5129.5 x 4.4-6-10.3 $\mu \mathrm{m}$ for 2017_SIM05_003, 351.6-515.9624.5 x 12.2-19.3-28.7 $\mu \mathrm{m}$ for 2017_SIM05_004, 202.9220.5-234.5 x 5.2-7-9.2 $\mu \mathrm{m}$ for 2017 SIM05 005, 469.3582.8-668 x 8.7-14.7-27.7 $\mu \mathrm{m}$ for 2017_SIM05_006 and curved oxeas with dimension 334.4-468.5-540.3 x 10-17.4$26.6 \mu \mathrm{m}$ for 2017 SIM05 007

Habitat: Shallow reefs that possess by E locality

$\begin{array}{cl}\text { Family } & : \text { Chalinidae Gray, } 1867 \\ \text { Genus } & : \text { Haliclona Grant, } 1841 \\ \text { Subgenus } & : \text { Haliclona (Reniera) Schmidt, } \\ 1862 & : \text { Haliclona (Reniera) sp. } \\ \text { Species } & \end{array}$

\section{Haliclona (Reniera) sp.}

Material examined: three ex, field code 2017_SIM04_001 (Bengkala Island, sampling point D), 2017_SIM06_001 \& 2017_SIM06_003 (Teluk Dalam, sampling point $\mathrm{F}$ )

Description: Three specimens are attached to the mangrove roots. Specimen 2017_SIM04_001 possesses a grey-white color in life and turns into white pale in ethanol. Oscules are not clearly seen whereas, a structure like sharp projection is clear on its surface. This sponge possesses a crumble consistency. Specimen 2017_SIM06_001 possesses a black color in life and turns into pale black in ethanol and Oscules are clearly seen. These sponges possess a structure like black spaghetti and less crumble consistency Specimen 2017_SIM06_003 possess an orange color in life and turn into pale orange in ethanol. Oscules are also clearly seen whereas. This sponge possesses an encrusting form with less crumble consistency (Figure 19).

Skeleton : Three specimens possess a characteristic of Haliclona skeleton which is triangular form, isodictyal and connected with unispicular spicule. 2017_SIM06_003 possesses more sponging fiber flowed by 2017_SIM06_001. On the other hand, 2017_SIM04_001 possesses less spongin fiber.

Spicules: Oxeas with dimension of 163.3-207.5-243.1 x 6.6-11.7-18.6 $\mu \mathrm{m}$ for 2017_SIM04_001, 139.5-176.5-221.2 $\mathrm{x}$ 5.1-7.7-9.8 $\mu \mathrm{m}$ for $201 \overline{7}$ SIM $0 \overline{6} 001$ and 177.7-209.9248.7 x 4.9-8.2-10.9 $\mu \mathrm{m}$ for 2017_SIM06_003

Habitat: Mangrove lagoons that possessed by D \& F locality.

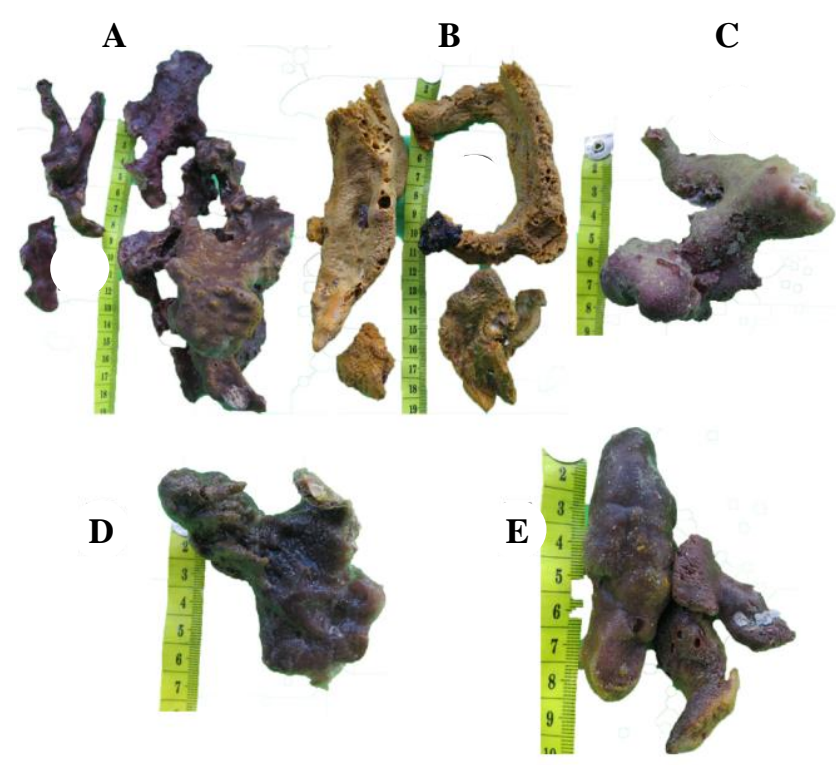

Figure 18.A. 2017_SIM05_003, B. 2017_SIM05_004, C. 2017_SIM05_005, D.2017_SIM05_006, E.2017_SIM05_007
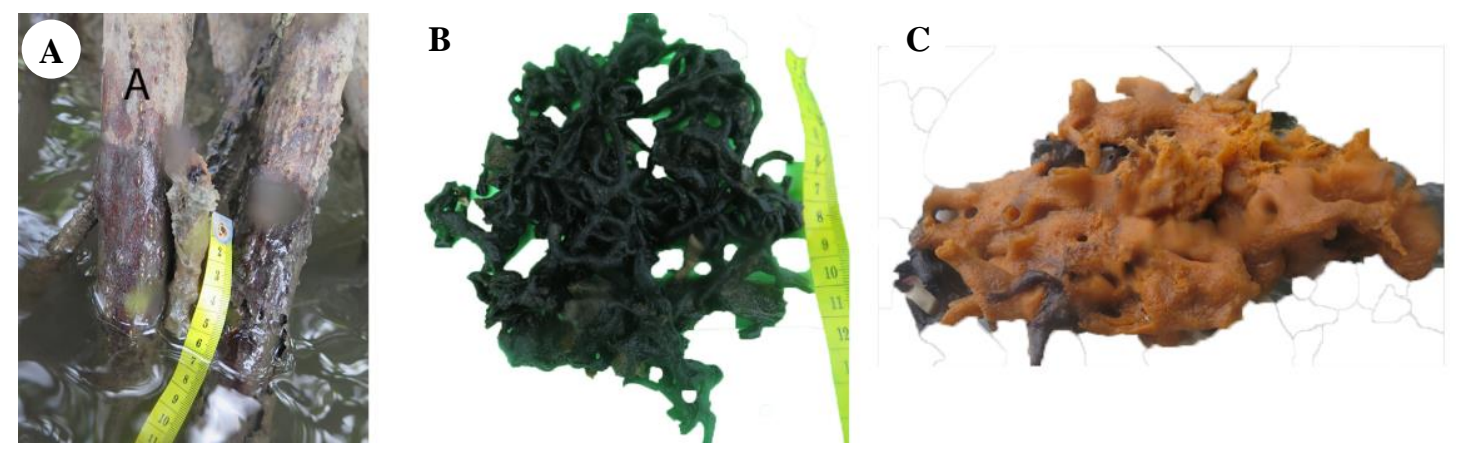

Figure 19.A. 2017_SIM04_001, B. 2017_SIM06_001, C. 2017_SIM06_003 


\section{Discussion}

We divided our sampling area into three categories that are shallow reefs, shallow sandy and mangrove lagoons for comparing our collected specimens into the list of officially recorded specimens from World Porifera Database (WPD). By comparing this, we could assess whether collected specimens are distributed endemically for a specific area of marine ecoregion or not since sponges are categorized as a marine benthic animal that possesses a high endemicity (Blanquer and Uriz 2007; Blanquer and Uriz 2008; Xavier et al. 2010; Reveillaud et al. 2011). Furthermore, this information also can be used as benchmark data for marine conservationists or ecologists who need to assess important marine benthic that inhabit their marine ecoregion, especially there has not yet any data published on shallow water of sponges from this Simeulue islands.

Twenty-three specimens were collected on shallow reefs in locality $\mathrm{A}$, and $\mathrm{E}$. Identified specimens are Acanthella cavernosa, Hyrtios erectus, Coscinoderma sp, Lamellodysidea herbacea, Petrosia corticata, Petrosia nigricans, Petrosia sp., Oceanapia fistulosa. According to WPD, these species inhabit a broad distribution area called West Indo-Pacific marine ecoregion (Spalding et al. 2007). The region covers a broad area from the eastern coast of Africa and the Red Sea in the west to the islands of Micronesia, Melanesia, Polynesia, and Indonesia in the east, continues until northern part limited to coasts of Korea, southern Japan, Hawaiian Islands, and southern part until Sharks Bay of Australia on the west part and Sydney on the eastern part. Even in our record one identified species as Ircina ramose is also inhabit a broader geographical area until the east coast of Pacific in Brazil. On the other hand, one identified species as Paratettila aruensis is recognized to be limited in Spermonde Indonesia (Arafura Sea). Because there has not yet any published study of sponges' diversity on the west coast of Sumatra, we could compare only our identified species to only one recently record sponges species published in Ubare and Mohan (2018) from in the Andaman Islands in the Southeast Indian Peninsula. This archipelago is close to West Sumatra coast and sea, including Simeulue Islands. Only one identified species as Oceanapia fistulosa from our specimen in the shallow reefs Simeulue is also recorded in Andaman Island from Mohan's record.

Sixteen specimens were collected from shallow sandy lagoons from locality B and C. Those identified species are Hyrtios erectus, Dactylospongia elegans, Carteriospongia foliascens, Lendenfeldia dendyi, Ircinia ramose, Lamellodysidea chlorea, Biemna fortis, and Spheciospongia inconstans. Similar to result on shallow reefs on locality A and E, most of the identified sponges on the shallow sandy lagoon on locality $\mathrm{B}$ and $\mathrm{C}$ have a cosmopolite distribution that inhabits West Indo-Pacific marine ecoregion. Furthermore, one identified species as Biemna fortis and one genera Spheciospongia are also recorded to the record of sponges from Ubare and Mohan (2018) in the Andaman Islands. A difference composition of sponges between shallow reefs and sandy lagoon in this study is the domination of specimens from subclass Keratosa sponges. Keratosa is sponge group that possesses fewer spicules mineral in its skeleton structures. It might also relate to the habitat of sandy lagoon since high turbidity in sandy lagoons could influence sponges composition. However, further investigations are still needed in the future.

The lowest amount of seven specimens were recorded on the mangrove lagoons from locality D, and F. Identified species is Biemna fortis, Oceanapia fistulosa, Haliclona sp., and Dysidea sp. Those species are also recognized as species that inhabit west Indo-Pacific marine ecoregion. Furthermore, two species Biemna fortis, Oceanapia fistulosa is also found in a recent record by Ubare and Mohan (2018). Mangrove lagoons is also an area with an extremely high and low tide, especially in Indo-Pacific (see review in Maldonado et al. 2015). Therefore, it might limit sponge diversity in Mangrove lagoon in comparison to shallow reefs and sandy lagoons in this study.

Species composition of identified sponges in shallow water of Simeulue on three different localities consists of sponges that usually inhabit West Indo-Pacific marine ecoregion. Furthermore, each different locality observed in this island possesses a different composition and number of species that might be related to a different characteristic of habitat that consists of Shallow reefs, sandy, and mangrove lagoons. Moreover, none of the recorded sponge species in Simeulue is specifically inhabited or possessing an endemic species in this area, cosmopolitism of shallow-water sponges that inhabit Simeulue also corroborated previous researches because most of those recorded species, e.g., Biemna fortis, Spheciospongia inconstans, Haliclona sp. and Petrosia sp. were discovered in a broader scale in Indonesia, e.g., in the southern part of Java Island (Hadi et al. 2018), Berau in the eastern part of East Kalimantan (Becking, Cleary, and de Voogd 2013), Bangka island in the north part of North Sulawesi (Calcinai et al. 2016), and in the western part of Timor Leste (Farnham and Bell 2018). Besides non-endemism or cosmopolitism on species composition, shallow water sponges in Simeulue also share habitat similarity mainly, despite unidentical, with other shallow-water sponges recorded from those locality e.g., Hyrtios erectus, Biemna fortis, and Spheciospongia inconstant recorded in Simeulue also inhabit shallow reef and sandy lagoon in the southern part of Java Island (Hadi et al. 2018), Berau in the eastern part of East Kalimantan (Becking, Cleary, and de Voogd 2013), Bangka island in the north part of North Sulawesi (Calcinai et al. 2016) see detail in Table 2.

Limitations during this research were occurring when we could not delimit and unravel some of the sponges samples until species level. This usually occurred because sponges are categorized as metazoans that possess limited morphological features. In addition, these reduced morphological characters in sponges such as color, shape and skeletal elements are influenced by environmental conditions called phenotypic plasticity (Bell and Barnes 2000; Bell and Barnes 2001; Hill and Hill 2002). For this reason, utilizing a method called as a bar-coding is obviously suggested to be added and combined with the classical method in the following and future study, because this method has been promoted as useful an aid for unraveling and delimiting sponges species (Wörheide and Erpenbeck 2007; Wörheide et al. 2007). 
Table 2. Presence of species for each habitat type in Simeulue Island, Aceh Province, in comparison to other studies in Indonesia

\begin{tabular}{|c|c|c|c|c|c|c|c|}
\hline Localities & $\begin{array}{c}\text { Location } \\
\text { A \& E }\end{array}$ & $\begin{array}{c}\text { Location } \\
\text { B \& C }\end{array}$ & $\begin{array}{c}\text { Location } \\
\text { D \& F }\end{array}$ & $\begin{array}{c}\text { Berau, East } \\
\text { Kalimantan } \\
\text { (Becking et al. } \\
\text { 2013) }\end{array}$ & $\begin{array}{l}\text { Bangka } \\
\text { Island, } \\
\text { North } \\
\text { Sulawesi } \\
\text { (Calcinai et } \\
\text { al. 2016) }\end{array}$ & $\begin{array}{c}\text { Southern } \\
\text { coastal of } \\
\text { Java Island } \\
\text { (Hadi et al. } \\
\text { 2018) }\end{array}$ & $\begin{array}{c}\text { Western } \\
\text { part of East } \\
\text { Timor } \\
\text { (Farnham } \\
\text { and Bell } \\
\text { 2018) }\end{array}$ \\
\hline Habitat & $\begin{array}{c}\text { Shallow } \\
\text { reefs }\end{array}$ & $\begin{array}{c}\text { Shallow } \\
\text { sandy } \\
\text { lagoon }\end{array}$ & $\begin{array}{c}\text { Mangrove } \\
\text { lagoon }\end{array}$ & $\begin{array}{c}\text { Shallow } \\
\text { sandy, reef \& } \\
\text { mangrove } \\
\text { lagoons }\end{array}$ & $\begin{array}{l}\text { Mangrove } \\
\text { lagoon }\end{array}$ & $\begin{array}{c}\text { Shallow } \\
\text { reefs }\end{array}$ & $\begin{array}{c}\text { Shallow } \\
\text { reefs }\end{array}$ \\
\hline Hyrtios erectus (Keller, 1889) & + & + & - & + & + & + & - \\
\hline Dactylospongia elegans (Thiele, 1899) & - & + & - & - & - & - & - \\
\hline Carteriospongia foliascens (Pallas, 1766) & - & + & - & - & - & - & - \\
\hline Lendenfeldia dendyi (Lendenfeld, 1889) & - & + & - & - & - & - & - \\
\hline Ircinia ramosa (Keller, 1889) & + & + & - & - & - & + & - \\
\hline Lamellodysidea chlorea (de Laubenfels, 1954) & - & + & - & + & - & - & - \\
\hline Lamellodysidea herbacea (Keller, 1889) & - & + & - & + & - & + & + \\
\hline Dysidea sp & - & - & + & + & + & + & - \\
\hline Coscinoderma sp & + & - & - & - & - & - & - \\
\hline Acanthella cavernosa Dendy, 1922 & + & - & - & - & - & + & - \\
\hline Biemna fortis (Topsent, 1897) & - & + & + & + & + & + & - \\
\hline Spheciospongia inconstans (Dendy, 1887) & - & + & - & + & + & + & + \\
\hline Paratetilla aruensis Hentschel, 1912 & + & - & - & + & + & + & + \\
\hline Oceanapia fistulosa (Bowerbank, 1873) & + & - & + & - & - & + & - \\
\hline Petrosia (Strongylophora) corticata (Wilson, 1925) & + & - & - & + & + & + & - \\
\hline Petrosia (Petrosia) nigricans Lindgren, 1897 & + & - & - & + & + & + & - \\
\hline Petrosia (Petrosia) sp & + & - & - & + & + & + & - \\
\hline Haliclona (Reniera) sp & - & - & + & + & + & + & - \\
\hline
\end{tabular}

\section{ACKNOWLEDGEMENTS}

The author would like to thank Research Center of Oceanography (P2O), Indonesian Institute of Sciences (LIPI), Jakarta, Indonesia that finance and give a grant for doing this research through annual research trip of Ekspedisi Widya Nusantara X (E-WIN X) coastal chapter. Likewise, to the local government of Simeulue who provide all of the sampling facility and local field assistant who guide and help the author during the collection process of sponges' material. Moreover, the author also appreciates the Department of Biology, Institut Teknologi Sepuluh Nopember, Surabaya, Indonesia that facilitates the usage of all utilities in Zoology and Animal Engineering Lab during the process of sponges' identification and manuscript writing.

\section{REFERENCES}

Barber, PH, Bellwood DR. 2005. Biodiversity hotspots: evolutionary origins of biodiversity in wrasses (Halichoeres: Labridae) in the IndoPacific and new world tropics. Mol Phylogenet Evol 35 (1): 235-53. DOI: 10.1016/j.ympev.2004.10.004.
Becking LE, Cleary DFR, Voogd NJ de. 2013. Sponge species composition, abundance, and cover in marine lakes and coastal mangroves in Berau, Indonesia. Mar Ecol Progr Ser 481: 105-120.

Bell JJ. 2008. The functional roles of marine sponges. Estuar Coast Shelf Sci 79 (3): 341-353.

Bell JJ, Barnes DKA. 2001. Sponge morphological diversity: a qualitative predictor of species diversity? Aquat Conserv Mar Freshw Ecosyst 11 (2): 109-21. DOI: $10.1002 /$ aqc. 436.

Bell JJ, Barnes DKA. 2000. The influences of bathymetry and flow regime upon the morphology of sublittoral sponge communities. J Mar Biol Assoc UK 80 (04): 707-718.

Blanquer A, Uriz M. 2008. 'A posteriori' searching for phenotypic characters to describe new cryptic species of sponges revealed by molecular markers (Dictyonellidae: Scopalina). Rev Invert Syst 22 (5): 489-502.

Blanquer A, Uriz MJ. 2007. Cryptic speciation in marine sponges evidenced by mitochondrial and nuclear genes: A phylogenetic approach. Mol Phylogenet Evol 45 (1): 392-397. DOI: 10.1016/j.ympev.2007.03.004.

Calcinai B, Bastari A, Makapedua DM, Cerrano C. 2016. Mangrove sponges from Bangka Island (North Sulawesi, Indonesia) with the description of a new species. J Mar Biol Assoc UK 97 (6): 1417-22. DOI: $10.1017 / \mathrm{S} 0025315416000710$.

de Goeij JM, van Oevelen D, Vermeij MJA, Osinga R, Middelburg JJ, de Goeij AFPM, Admiraal W. 2013. Surviving in a marine desert: the sponge loop retains resources within coral reefs. Science 342 (6154): 108-110.

Diaz MC, Rutzler K. 2001. Sponges: an essential component of Caribbean coral reefs. Bull Mar Sci 69 (2): 535-546. 
Erpenbeck D, Aryasari R, Benning S, Debitus C, Kaltenbacher E, Al Aidaroos AM, Schupp P, et al. 2017. Diversity of two widespread Indo-Pacific demosponge species revisited. Mar Biodiv 47 (4): 1035 1043. DOI: $10.1007 / \mathrm{s} 12526-017-0783-3$.

Farnham ES, Bell JJ. 2018. Spatial Variation in a Shallow-Water SpongeDominated Reef in Timor-Leste (East Timor). Pacific Sci 72 (2): 233 45.

Hadi TA, Hafitz M, Hadiyanto H, Budiyanto A, Siringoringo RM. 2018. Shallow water sponges along the south coast of Java, Indonesia. Biodiversitas 19 (2): 485-493.

Hill MS, Hill AL. 2002. Morphological plasticity in the tropical sponge Anthosigmella varians: responses to predators and wave energy. Biol Bull 202 (1): 86-95.

Hoeksema B. 2007. Delineation of the Indo-Malayan centre of maximum marine biodiversity: the coral triangle. In: Renema W (ed.) Biogeography, Time, and Place: Distributions, Barriers, and Islands. Springer, Netherlands.

Hooper JNA, van Soest RWM. 2002. Systema Porifera: a guide to the classification of sponges. 2 vols: Kluwer Academic/Plenum Publishers, Netherlands.

Kochzius M, Seidel C, Hauschild J, Kirchhoff S, Mester P, MeyerWachsmuth I, Nuryanto A, Timm J.. 2009. Genetic population structures of the blue starfish Linckia laevigata and its gastropod ectoparasite Thyca crystallina. Mar Ecol Progr Ser 396: 211-219. DOI: $10.3354 /$ meps08281.

Kochzius M, Nuryanto A. 2008. Strong genetic population structure in the boring giant clam, Tridacna crocea, across the Indo-Malay Archipelago: implications related to evolutionary processes and connectivity. Mol Ecol 17 (17): 3775-87. DOI: 10.1111/j.1365294X.2008.03803.X.

Maldonado M, Aguilar R, Bannister RJ, Bell JJ, Conway KW, Dayton PK, Díaz C, et al. 2015. Sponge grounds as key marine habitats: a synthetic review of types, structure, functional roles, and conservation concerns. In: Rossi S, Bramanti L, Gori A, Saco del Valle CO (eds.).
Marine Animal Forests: The Ecology of Benthic Biodiversity Hotspots. Springer International Publishing, Cham.

Reveillaud J, van Soest RWM, Derycke S, Picton B, Rigaux A, Vanreusel A. 2011. Phylogenetic relationships among NE Atlantic Plocamionida Topsent (1927) (Porifera, Poecilosclerida): Underestimated diversity in reef ecosystems. PLoS One 6 (2): e16533. DOI: 10.1371/journal.pone.0016533.

Spalding MD, Fox HE, Allen GR, Davidson N, Ferdaña ZA, Finlayson M, Halpern BS, et al. 2007. Marine ecoregions of the world: A Bioregionalization of coastal and shelf areas. BioScience 57 (7): 57383. DOI: 10.1641/B570707.

Timm J, Planes S, Kochzius M. 2012. High similarity of genetic population structure in the false clown anemonefish (Amphiprion ocellaris) found in microsatellite and mitochondrial control region analysis. Conserv Genet 13 (3): 693-706.

Ubare VV, Mohan PM. 2018. New records and range extensions of some marine sponges (Porifera: Demospongiae and Homoscleromorpha) from the Andaman Islands, India; Part of the Indo-Burma Biodiversity Hotspot. Zool Stud 3. DOI: 10.6620/ZS.2018.57-03.

van Soest RWM, Boury-Esnault N, Hooper JNA, Rützler K, de Voogd NJ, Alvarez de Glasby B, Pisera AB, et al. 2018. World Porifera database. http: //www.marinespecies.org/porifera.

Wörheide G, Erpenbeck D. 2007. DNA taxonomy of sponges - progress and perspectives. J Mar Biol Assoc UK 87 (6): 1629-1633.

Wörheide G, Erpenbeck D, Menke C. 2007. The sponge barcoding project - aiding in the identification and description of poriferan taxa. In: Custódio MR, Lôbo-Hajdu G, Hajdu E, Muricy G (eds.). Porifera Research : Biodiversity, Innovation and Sustainability. Museu Nacional Serie Livros, Rio de Janeiro, RJ, Brasil.

Xavier JR, van Soest RWM, Breeuwer JA, Martins AM, Menken SB.. 2010. Phylogeography, genetic diversity and structure of the poecilosclerid sponge Phorbas fictitius at oceanic islands. Contrib Zool 79 (3): 119-29. 